\title{
KEBANGKITAN MASJID KAMPUS DI YOGYAKARTA: EKSKLUSIF ATAU INKLUSIF?
}

\author{
AF. Djunaidi \\ Lukman A. Irfan \\ Edi Safitri \\ Dosen Fakultas Ilmu Agama Islam Universitas Islam Indonesia, Yogyakarta. \\ 904220102@uii.ac.id \\ lukmanairfan@gmail.com \\ edy_pasca@yahoo.com
}

\section{Abstract}

This research is motivated by the phenomenon of religious activities in mosques strengthening campus in Yogyakarta. The phenomenon of the strengthening of religious activity on campus is obviously very interesting to study. Moreover, the phenomenon has a tendency exclusive then the mosque likewise; The programs and activities actually mosque campus have a common goal that is about to present Islam in the middle of campus and community that was changing it shows the tendency that leads to what is known as "exclusivism of religion." The subjects were four mosques campuses, namely the mosque at UGM, UNY, UII, and UIN Sunan Kalijaga. Methods of data collection in this study includes surveys, participatory observation, in-depth interviews (depth interview), and field notes. This study found that: Mosque campus has its own characteristics depending takmir or board mosque and activists. Tendency to exclusivity comes on board mosque. Then, the management of the campus mosque ideally an early forerunner of the strengthening of religious movements. This religious movement to bring the interaction between activists intensified so through a process of internalization grow and shape the character.

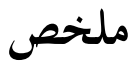

قد كانتعزيز ظاهرة النشاط الديني في مسجد الجامعة في يوغياكارتاخلفية لذذه الدراسة.ظاهرة تعزيز النشاط الديني في الجامعةمهمة للدراسة. وعلاوة على ذلك، تظهر تلك الظاهرة الميل الذي يؤدي إلى ما يعرف باسم "التفرد الديني". وكان أربعة مواد مسجد الجامعة وهي مسجد في جامعة غاجاه مادا، جامعةيوغياكارتا الحكومية، 
الجامعة الإسلامية الإندونيسية، وجامعة سونان كاليجاغا الإسلامية الحكومية. طرق همع البيانات في هذه الدراسة تشمل المسوحات والمراقبة التشاركية، مقابلات معمقة (مقابلة العمق)، والملاحظات الميدانية. وجدت هذه الدراسة ما يلي: (1) مسجد الجامعة خصائصهحسب المعمرين وناشطيه. الميل إلى التفرد يأتي من قبل معمريه. إذا كان المعمرون لديهم ميل التفرد ثم المسجد أيضا. (r) برامج وأنشطة مسجد الجامعة تنبغي إن تكون لديهم هدف مشترك وهذا هو على وشك تقديم الإسالام في وسط الجامعةوالبحتمع على وجهالتغير من الناحية السياسية والاقتصادية والثقافية والاجتماعية في الواقع. (T) إدارة مسجد الجامعةبشكل مثالي هي سبب تعزيز الحركات الدينية. هذه الحركة الدينية تحقق تفاعل التواصل بين النشطاء فمن هنابوسيلة عملية الإستيعاب يتطور الأخلاق الشخصية أو الشخصية المغيرة المتقدمة.

Kata Kunci: Masjid, Kampus, Ekslusif, DIY.

\section{A. Pendahuluan}

Kampus adalah merupakan unit terdepan dalam implementasi sistem pendidikan nasional. Sesuai dengan ideologi Negara dan budaya Bangsa Indonesia, maka implementasi sistem pendidikan nasional dan sistem pelatihan kerja yang dilakukan di Indonesia pada setiap level kualifikasi pada Kerangka Kualifikasi Nasional Indonesia (KKNI) mencakup proses yang membangun karakter dan kepribadian manusia Indonesia yang, di antaranya menghasilkan sarjana yang menghargai keanekaragaman budaya, pandangan, kepercayaan, dan agama serta pendapat/temuan original orang lain. Masjid merupakan rumah ibadah bagi umat Islam, maka tak heran masjid memiliki peran sentral dalam menggerakkan aktivitas keagamaan maupun sosial sehingga kehadiran masjid sebuah keharusan. Di beberapa perguruan tinggi, bahkan terlihat masjid menjadi alternatif pilihan untuk mengisi waktu diluar kegiatan perkuliahan normal. Kenyataan ini terus berkembang, sehingga masjid kampus berfungsi 
bukan saja untuk kepentingan kegiatan keagamaan (ibadah) tapi juga jenis kegiatan lainnya seperti kelompok belajar, kegiatan seni budaya, latihan kepemimpinan dan lain sebagainya.

Pelebaran fungsi masjid seperti itu sebenarnya bukan sesuatu yang baru, bahkan merupakan proses idealisasi sesuai dengan fungsi yang sesungguhnya seperti terjadi pada zaman Nabi Muhammad SAW. Kenyataan di masyarakat memang masih memperlihatkan fungsinya yang sangat sempit. Masjid, secara umum seringkali diidentikkan sebagai tempat ibadah. Di luar itu, masjid seolaholah tidak memiliki fungsi sosial apapun. Maka perlu optimalisasi fungsi masjid bukan hanya dalam aspek kegiatan ibadah ritual tapi juga pembinaan aspek wawasan sosial, politik, dan ekonomi serta wawasan-wawasan lainnya sesuai dengan tuntutan dan perkembangan zaman.

Optimalisasi fungsi seperti inilah yang terjadi di masjid-masjid kampus yang dari sisi kualitas sumber daya jama'ahnya relatif lebih maju. Masjid kampus umumnya dikelola melalui manajemen yang lebih baik dibanding masjid-masjid pada umumnya. Hal ini karena para aktivitas adalah warga kampus dengan konsentrasi kegiatan yang belum terbagi. Menurut Zuly Qodir ${ }^{1}$ fenomena pergeseran dan menguatnya gerakan keagamaan di kampus setidaknya ada beberapa alasan. Pertama, gejala kebangkitan Islam di kampus cukup kentara dibanding dengan gerakan keagamaan lain. Gejala kebangkitan ini ditandai, misalnya perubahan dalam gaya hidup mahasiswa. Contohnya kebanyakan para mahasiswi yang terlibat dalam kegiatan keagamaan dikampus menggenakan jilbab dan menggunakannya sebagai pakaian muslimah. Kedua, kebangkitan keislaman di kalangan mahasiswa bukan hanya di kampus sekuler seperti Universitas Gajah Mada (UGM) dan Universitas Negeri Yogyakarta (UNY), tetapi juga di kampus Islam seperti Univrsitas Islam Negeri (UIN) Sunan Kalijaga dan Universitas Islam Indonesia (UII). Ketiga, aktivitas keIslaman dimasukkan kedalam program kemahasiswaan termasuk penyelenggaraan Kuliah Aqidah dan KeIslaman di kampus. Keempat, aktivitas mereka telah melahirkan ide-ide baru yang mereka praktekkan dalam upaya menerapkan konsep-konsep Islam.

1 Qodir, Zuly dkk. “Islam Kampus Dalam Perubahan Politik Nasional: Studi Keislaman Masjid UGM, UNY, UIN Sunan Kalijaga, UII dan UMY Provinsi Daerah Istimewa Yogyakarta”. (Yogyakarta: Sekolah Pasca Sarjana Universitas Gadjah Mada, 2010). 
Faktor lain dari menguatnya keIslaman mahasiswa di kampus adalah saat ini kampus sudah didukung oleh berbagai fasilitas keagamaan yang semakin lengkap. Di satu sisi menguatnya aktivitas keagamaan di sejumlah kampus melalui Lembaga Dakwah Kampus (LDK). Hal ini karena kegiatan ini telah mempengaruhi kesadaran keagamaan mahasiswa di luar kampus. Dilihat dari cakupan penyebaran dari waktu ke waktu mengalami kemajuan. Jika di awal reformasi hanya menjaring basis kampus dan urban, akan tetapi akhir-akhir ini masjid-masjid diperkotaan sudah banyak yang dikuasai.

Dewasa ini beberapa peneliti kajian keislaman mahasiswa di kampuskampus, seperti Azumardi Azra² membagi corak berpikir keagamaan mahasiswa ke dalam tiga kelompok: Pertama, yang merupakan mayoritas adalah kelompok "common" Muslim, yakni para mahasiswa Muslim yang mengamalkan ajaran Islam seadanya serta cenderung tradisional dan konvensional. Kedua, adalah para mahasiswa yang berlatar belakang keagamaan sangat kuat dan mereka yang merasa perlu mengembangkan dirinya, yang dalamkonteks keagamaanadalah untuklebihmeningkatkan pemahaman mereka tentang Islam, dan dalam konteks akademis adalah untuk meningkatkan kemampuan berorganisasi dan ketrampilan ilmiah. Di masa lalu, kelompok mahasiswa demikian cenderung memilih dan bergabung dengan organisasi kemahasiswaan Islam, terutama Himpunan Mahasiswa Islam (HMI), Pergerakan Mahasiswa Islam Indonesia (PMII), dan Ikatan Mahasiswa Muhammadiyah (IMM). Ketiga, yakni kelompok mahasiswa yang lebih berorientasi kepada pengamalan Islam secara menyeluruh, kaffah. Kelompok-kelompok mahasiswa ini, apa karena pengaruh gerakan organisasi internasional Islam Ikhwanul Muslimin (Mesir), Jama`at Islami (Pakistan), dan organisasi-organisasi internasional lainnya, atau sebagai hasil kreasi lokal para mahasiswa Islam Indonesia, mereka mengadakan pengkajian-pengkajian Islam

2 Azyumardi Azra, “Kelompok 'Sempalan' di Kalangan Mahasiswa PTU: Anatomi Sosio-Historis", dalam Fuaduddin \& Cik Hasan Bisri, (ed), Dinamika Pemikiran Islam di Perguruan Tinggi, (Ciputat: Logos, 2002), hal. 224. 
secara intensif dalam bentuk Usrah-usrah. Kelompok mahasiswa Islam ini pula yang kemudian mendirikan kegiatan Mentoring atau Tutorial keagamaan di masjid-masjid kampus, termasuk Pesantren Kilat bagi para pelajar SD, SLTP, dan SLTA.

Di Yogyakarta, kecenderungan menguatnya kegiatan keagamaan di sejumlah kampus terlihat banykanya kegiatan keagamaan seperti halaqah, pengajian, kursus Islam, dan sebagainya. Bahkan bila memasuki bulan Ramadhan, kegiatan keagamaan di sejumlah kampus itu semakin menunjukkan aktivitas keagamaan yang cukup semarak dan meriah. ${ }^{3}$

Observasi awal ${ }^{4}$ yang dilakukan peneliti terhadap empat masjid di kampus besar, yaitu UGM, UIN, UII, dan UNY, telah memperkuat pernyataan di atas. Setidaknya peneliti menemukanadanya semacam kegiatan yang tersistem untuk menghidupkan kembali masjid lewat berbagai aktivitas yang diselenggarakan oleh lembaga masjid kampus. Kegiatan tersebut meliputi penyelenggaraan pengajian rutin, diskusi keagamaan secara periodik, serta berbagai kegiatan dakwah yang dilakukan secara intensif, baik di internal (anggota jamaah) maupun eksternal kampus (masyarakat umum).

Fenomena menguatnya kegiatan keagamaan di kampus jelas sangat menarik untuk dikaji. Setidak-tidaknya terdapat empat alasan. Pertama, gejala menguatnya kegiatan keagamaan Islam di kampus relatif lebih terlihat dibanding dengan gerakan keagamaan di luar. Fenomena ini berlangsung hampir banyak kampus di Indonesia, termasuk Yogyakarta. Gejala kebangkitan ini ditandai, misalnya, oleh perubahan revolusioner dalam gaya hidup mahasiswa. Perubahan yang paling terlihat adalah dalam penggunaan busana muslimah sebagai identitas mahasiswi di kampus. Kedua, menguatnya kegiatan keagamaan di kalangan mahasiswa dimulai dari kampus-kampus sekuler dan bukan di kampus-kampus Islam seperti IAIN (sekarang beberapanya berganti nama menjadi Universitas Islam Negeri). Ketiga, kegiatan keagamaan yang diselenggarakan bukanlah temporer tetapi dimasukkan di dalam program kemahasiswaan. Keempat, kegiatan keagamaan tersebut telah melahirkan ideide baru yang dipraktikkan dalam upaya menerapkan konsep-konsep Islam tentang masalah tertentu yang tidak dilakukan sebelumnya (Jamas, 2005).

\footnotetext{
3 Hasil observasi selama Ramadhan tahun 2007.

4 Hasil Observasi di Januari 2006.
} 
Faktor lain yang tidak kalah penting dari menguatnya kegiatan keagamaan mahasiswa berbasis kampus adalah bahwa saat ini kampus sudah didukung oleh berbagai fasilitas keagamaan yang semakin lengkap. Jika beberapa tahun yang lalu, sekitar 1980-an sejumlah kampus di Jogja belum dilengkapi masjid --kecuali kampus Islam-- maka sekarang hampir di semua kampus sudah mempunyai masjid atau setidak-tidaknya mushalla. Oleh karena itu, dengan berdirinya masjid di kampus ini, maka kegiatan keagamaan kini menjadi semakin meningkat dan semarak. Begitu pula dengan aktifis masjid kampus kini juga semakin banyak.

Pada satu sisi, menguatnya kegiatan keagamaan di sejumlah kampus melalui lembaga masjid sangat positif dan perlu didukung oleh semua pihak. Hal ini karena kegiatan tersebut telah mempengaruhi kesadaran keagamaan mahasiswa di luar kampus. Ketika di luar kampus mahasiswa juga mengadakan berbagai kegiatan di masjid-masjid umum dan menyebut dirinya "remaja masjid." Namun pada sisi lain, menguatnya kegiatan tersebut semakin hari semakin menunjukkan kecenderungan yang mengarah pada apa yang dikenal sebagai "eksklusivisme keagamaan."

Eksklusivisme tersebut dapat dicermati dari data awal yang diperoleh penulis, yaitu berdasar tanggapan jamaah yang menjadi responden penelitian. Ketika disodori pertanyaan tentang sikap jamaah terhadap bantuan yang diberikan oleh non-muslim, tanggapan yang diberikan adalah menolak dengan alasan bahwa menerima bantuan tersebut haram karena bersumber dari orang kafir. Tanggapan selanjutnya adalah ketika disodori pertanyaan tentang siapa yang harus terlebih dahulu ditolong jika terjadi musibah yang menimpa muslim dan non muslim secara bersamaan. Tanggapan jamaah adalah lebih mengedepankan muslim, atau lebih spesifik kelompoknya, dengan alasan bahwa orang-orang kafir adalah musuh. ${ }^{5}$

Tanggapan di atas menjadi indikasi sekaligus data awal bahwa kegiatan keagamaan yang berlangsung di masjid kampus mengarah pada sikap eksklusif. Adapun yang dimaksud dengan eksklusivisme keagamaan dalam konteks ini adalah sikap yang memandang bahwa keyakinan, pandangan, pikiran, serta prinsip diri dan kelompok sendirilah yang paling benar sementara keyakinan, pandangan, pikiran dan prinsip orang serta kelompok lain salah, sesat,

5 Hasil wawancara tanggal 14 Januari 2007. 
dan harus dijauhi (Wijdan, 2004) ${ }^{6}$. Pendek kata, eksklusivisme keagamaan merupakan suatu paham keagamaan yang tidak terbuka dalam pergaulan dengan kelompok lain.

Menurut Nasr Hamid Abu Zaid ${ }^{7}$ ada lima pola dari wacana keagamaan dewasa ini yang tertutup (eksklusif). Pertama, menyatukan antara agama dan pemikiran keagamaan (ijtihad). Jarak pemisah antara keduanya tidak dipisahkan secara jelas, sehingga jika ada pemahaman lain yang bertentangan dengan pemahamannya dianggap melanggar agama. Kedua, teologisasi fenomena sosial dan alam. Dalam wacana ini, hukum kausalitas tidak dilihat sebagai faktor utama. Semua kejadian baik yang pada dasarnya realitas sejarah dan sosial dikembalikan kepada Allah. Akhirnya pemahaman ini mendorong manusia untuk malas, tidak mempunyai etos kerja, dan lebih bersifat fatalis. Manusia tidak mempunyai kebebasan untuk berkemauan apalagi bertindak. Ketiga, interdepedensi (ketergantungan) terhadap salaf dan tradisi (turats). Kelompok ini memandang masa lalu adalah segala-galanya. Hasil karya ulama terdahulu sudah melebihi dari cukup dan tugas sekarang sekedar mempraktikkannya. Perbedaan pendapat tidak dihargai jika bertentangan dengan pendapat tradisi dan ulama salaf.

Keempat, fanatisme pendapat dan menolak dialog. Setelah kelompok ini berlindung di balik tradisi (turats), mereka memiliki otoritas sendiri untuk menafsirkan tradisi ini. Otoritas ini hanya dimiliki oleh kelompok mereka, sedangkan kelompok lain tidak memiliki kebebasan untuk menafsirkan. Kelima, mengingkari dimensi historis. Pola pikir ini sebagai akibat dari pola-pola di atas. Hukum perubahan dan pergantian dipahami dari sudut teologi daripada proses sejarah dan sosial. Tidak jarang, konsep-konsep yang pada mulanya tidak ada dalam ajaran Islam diyakini sebagai ajaran agama karena memiliki sejarah dan terjadi di komunitas islam, seperti konsep negara Islam. ${ }^{8}$

Sikap eksklusif dapat dibagi menjadi dua bagian: (1) Eksklusif ke luar dan (2) Eksklusif ke dalam. Eksklusif ke luar berarti meyakini agama Islam sebagai agama yang paling benar sedangkan agama lain dianggap sesat dan tidak akan diterima oleh Tuhan. Pandangan ini didasarkan pada ayat Al-Qur`an sebagai

\footnotetext{
6 Aden Wijdan, Pemikiran dan Peradaban Islam, (Yogyakarta, The Asia Fundation, 2004).

7 Nasr Hamid Abu Zayd, Al-Tafkir fi Zaman al-Takfir. (Kairo: Maktabah Madbuli, 1995), hal. 67.

8 Ibid., hal. 67.
} 
berikut: "Sesungguhnya agama (yang diridhai) di sisi Allah hanyalah Islam. Tiada berselisih orang-orang yang telah diberi Al-kitab kecuali sesudah datang pengetahuan kepada mereka, karena kedengkian yang ada di antara mereka. Barangsiapa yang kafir terhadap ayat-ayat Allah maka sesungguhnya Allah sangat cepat hishab-Nya." (QS. Ali Imron 3:19).

Paham Eksklusivisme berpendapat bahwa kata Islam yang terdapat pada ayat-ayat tersebut di atas adalah agama yang dibawa oleh nabi Muhammad SAW. Agama inilah yang diterima di sisi Allah sedangkan agama lainnya seperti Yahudi, Nasrani tidak diridhoi Tuhan. Agama-agama selain Islam dalam pengertian yang demikian itu adalah agama yang sesat, tidak akan diterima Tuhan dan akan mendatangkan kerugian di akhirat. Yang dimaksud dengan eksklusivisme ke dalam adalah pandangan, persepsi dan sikap yang terdapat di dalam Islam, yang mengakui bahwa hanya aliran eksklusivisme-lah yang benar, dan yang lainnya salah.

Diantara ciri-ciri kaum eksklusif, menurut fatimah ${ }^{9}$ yaitu: (1) Mereka yang menerapkan model penafsiran literal terhadap Al-Qur'an dan sunah dan masa lalu karena mengunakan pendekatan literal, maka ijtihad bukanlah hal yang sentral kerangka berfikir mereka, (2) mereka berpendapat bahwa keselamatan yang bisa dicapai melalui agama Islam. Bagi mereka, Islam adalah agama final yang datang untuk mengoreksi agama-agama lain. Karena itu mereka menggugat otentisitas kitab suci agama lain.

Kalau mengacu kepada tiga kecenderungan tersebut, maka kaum intelektual Muslim jika dilihat dari segi kajian keislamannya juga dapat dikategorikan menjadi tiga kelompok berdasarkan wawasan keilmuan: ${ }^{10}$ Pertama, kaum inetelektual Muslim yang hanya menerima ilmu-ilmu agama Islam tanpasentuhan ilmu-ilmu empiris dan historis-sosiologis,sehingga gagasannya bersifat eksklusif. Kedua, kaum intelektual Muslim yang mulai membuka relasi antara ilmu-ilmu agama Islam dengan ilmu-ilmu empiris dan historis-sosiologis atau sains Barat, tetapi masih berwatak apologis jika Islam dihadapkan dengan sains Barat. Ketiga, kaum intelektual Muslim yang berusaha

9 Fatimah, Muslim-cristian relations in the new order indonesia: the Exclusivits and Inclusivits muslim' perspective", 2004.

10 Din Syamsuddin, "Usaha Pencarian konsep Negara dalam sejarah Pemikiran Politik Islam” dalam Abu Zahra (ed.), Politik Demi Tuhan: Nasionalisme Religius di Indonesia, (Jakarta: Pustaka Hidayah, 1999). 
mensinergikan ilmu-ilmu agama Islam dengan ilmu-ilmu empris dan historissosiologis atau sains Barat, sehingga dialektika antara keduanya berjalan secara kritis dan konstruktif.

\section{B. Program-Program Lembaga Masjid Kampus}

Keberadaan lembaga yang mengatur kegiatan masjid kampus baik berbentuk yayasan maupun langsung di bawah pengawasan universitas merupakan bentuk keseriusan dalam memakmurkan dan meningkatkan peran masjid bagi warga kampus dan masyarakat pada umumnya. Seiring waktu peran dari lembaga masjid semakin vital, mengingat kebutuhan jama'ah akan ilmu keagamaan makin tumbuh dan permasalahan umat yang makin komplit. Tak jarang masjid yang manajemennya kurang baik dan penawaran program kegiatan yang kurang menarik akan ditinggal oleh jama'ah.

Dari hasil observasi ${ }^{11}$ empat masjid kampus di Yogyakarta yaitu, Masjid Kampus UGM, Masjid UIN SUKA, Masjid Ulil Albab UII, dan Masjid AlMujahidin UNY, masing-masing masjid kampus memiliki program rutin dan unggulan. Kajian rutin Masjid kampus UGM yaitu, ahad pagi dan sore, materinya tafsir. Selanjutnya hari rabu minggu pertama dan ketiga materinya tafsir. Sedangkan kamis sore, kajian menjelang buka puasa materinya lebih kontemporer. Sedangkan kegiatan-kegiatan luar masjid yang mengurusi dan mengerjakan program dari UKM Jama' ah Shalahudin (JS) dan JS tidak dibawah takmir. Namun, JS ada koordinasi dengan takmir karena sama-sama bertujuan memakmurkan masjid. Sementara kajian akbar kebanyakan digunakan oleh pihakluar, seperti kajian Ust Firanda Andirja dan KH Aa Gym yang didatangkan oleh Dompet Peduli Umat dan Tauhid (DPUD). Penggunaan masjid kampus UGM boleh dari kelompok mana saja asal tidak ada kegiatan di masjid, yang penting pas jadwalnya dan dalam koridor Qur'an dan Sunnah.

Kajian di masjid UIN SUKA sedikit bervariasi, Hasil penelitian di lapangan, tema pengajian di masjid Ulil Albab UII kebanyakan mengangkat tema tentang akhlak, ustadznya berbeda-beda sesuai dengan jadwal. Setiap satu bulan sekali mendatangkan PakLasiman mantan pendetaatau misionaris. Sementarapengajian rutin diadakan setiap malam kamis, malam jum'at, dan malam sabtu. Sedangkan malam selasa masjid dipakai

11 Observasi tahun 2007 dan tahun 2014. 
untuk belajar makhraj (belajar tajwid). Untuk forum pengajian rutin bentuknya tidak melingkar seperti model halaqah, tapi hadap-hadapan, di depan ada meja untuk penceramahnya. Antara penceramah dan audiens hadap-hadapan, tapi antara audiens laki-laki dan perempuan bersebelahan dibatasi oleh hijab.

Selain tema ibadah, parapengisi forum (Ustadz) merespon jugaisu-isu aktual seperti fatwa MUI tentang penyesatan Ahmadiyah dan para penceramah mendukung fatwa tersebut dan menolak aliran-aliran sesat seperti Ahmadiyah, termasuk tentang berbagai fenomena korupsi. Pada forum khutbah jumat banyak mengangkat masalah sosial, keagamaan, politik juga. Tapi jika di forum-forum pengajian yang diangkat kebanyakan masalah aqidah, ahklaq, ibadah ubudiyah dan isinya normatif, agak kanan-kananlah jika pakai istilah paham kanan-kiri.

Kajian rutin pada hari rabu, kamis, dan jum'at sudah mempunyai jama'ah tetap dan pembicaranya dari berbagai elemen, ada dari NU, Muhammadiah, Hizbut Tahrir Indonesia (HTI) Salafi, pokoknya terdiri dari berbagai elemen dan yang menentukan tema-tema atau arah kegiatan itu dari mahasiwa yang menjadi takmir. Termasuk menentukan penceramah seperti Ja' far Umar Thalib, Irfan Awwas itu dari mahasiswa dan dari DPPAI tidak terlalu intervensi untuk kegiatan-kegiatan yang bersifat kajian. Sedangkan untuk kegiatan non kajian kami punya pelatihan-pelatihan kalau boleh dibilang kita punya akademik Ulil Albab sebagai impianlah. Ada pelatihan adzan, tahsin dasar, tahsin lanjut, dan pelatihan imam.

Untuk audiens tidak ada undangan karena sudah rutin kegiatannya, namun dari pihak takmir setelah sholat magrib mengumumkan, sifatnya sekadar mengingatkan bahwa ada pengajian. Agar para jama'ah sholat maghrib yang hadir tidak meninggalkan masjid. Dari mereka yang mengikuti sholat magrib (berjamaah) sekitar 70\% mengikuti pengajian sementara 30\% meninggalkan masjid untuk kegiatan lain. Jumlah rata-rata yang hadir sekitar 40-50 orang jama'ah yang mengikuti, mayoritasnya mahasiswa, dari masyarakat umum ada 1 atau 2. Model forum ada dialog, tapi pakai tertulis di kertas, siapa yang mengajukan pertanyaan dengan tertulis nanti dijawab satu persatu.

Masjid kampus UIN SUKA mempunyai program tidak jauh berbeda dengan masjid kampus yang lain. Berdasarkan hasil survei mendalam bahwa pemakaian masjid kampus UIN Sunan Kalijaga untuk kegiatan ibadah terbuka untuk semua masyarakat, namun apabila pemakaian masjid kampus digunakan 
untuk kegiatan di luar aktivitas ibadah harus seizin ketua takmir. Untuk memakmurkan dan mengoptimalkan fungsi masjid takmir masjid dibantu oleh Lembaga Dakwah Masjid (LDM) dalam berbagai macam kegiatan.

Lembaga Dakwah Masjid (LDM) sangat terbuka bagi semua mahasiswa dari berbagai latar belakang. Dalam melakukan aktivitasnya, LDM lebih mengagendakan isu-isu sosial keagamaan. LDM selalu berkoordinasi dengan lembaga dakwah kampus yang terwadahi dalam Forum Silaturahmi Lembaga Dakwah Masjid (FSLDM). Terutama dalam menanggapi isu-isu yang sangat krusial, salah satunya Al-Qiyadah Al Islamiyah. Ada semacam kesepakatan dari FSLDM untuk meminimalisir pergerakan Al-Qiyadah Al-Islamiyah.

Salah satu rangkaian kegiatan di bulan ramadhan adalah Ramadhan 1.000 kreasi dalam bentuk lesehan Ramadhan. Tema yang diusung pun bermacammacam, mulai isu sosial-politik, ekonomi dan budaya, hingga tren generasi muda Islam. Adapun setelah shalat tarawih ada kegiatan Islamic Shortcourse, kegiatan ini diadakan untuk mengenalkan bagaimana Islam dipahami sebagai rahmatan lil 'alamin, yang mensyaratkan adanya pengakuan akan pluralitas keberagamaan. Untuk mendukung gagasan ini, dalam kajian diberikan pula tema kajian Al-Qur'an multidisipliner dan tafsir kontekstual dari Al-Qur'an, studi tentang hadits, fiqh praktis, tasawuf positif, sirah nabi, Islam dan kebebasan beragama, serta kajian filsafat dan politik. Menurut panitia, setelah shalat shubuh biasanya dilakukan tadarus.

Selain digunakan untuk melakukan ibadah, Menurut Rizki, dulu sebelum gempa, pada 27 Mei 2006, di masjid ada beberapa jamaah yang menggunakan masjid untuk melakukan kaderisasi. Salah satunya HTI. Namun setelah gempa, karena masjid hancur dan tidak dapat digunakan, mereka melakukan kegiatan di sekitar tempat parkir masjid lama. Sampai hari ini, HTI hampir tidak pernah menggunakan masjid sementara (gedung serba guna).

LDM berupaya untuk memahami pluralitas. Ini tercermin dari keterbukaan penggunaan masjid. Namun demikian, ada hal-hal yang tidak boleh dilakukan tanpa seizin takmir masjid, seperti tercantum dalam tata tertib yang ditempel pada pintu masuk ruangan masjid sementara. LDM, menurut Rizki, berperan seperti MUI, yang menaungi semua golongan dan aliran di lingkungan kampus UIN Sunan Kalijaga. Meskipun demikian, LDM tidak dapat melepaskan diri dari garis komando yang telah ditentukan oleh takmir maupun FSLDM. 
Masjid kampus Al Mujahidin UNY menghadirkan program kegiatan rutin dan kondisional. Program rutin yaitu, kajian-kajian, dilaksanakan hari senin sampai rabu, waktu pelaksanaannya ba'da maghrib sampai menjelang isya. Untuk pematerinya hari senin Ust Sholihul, hari selasa Ust Didin, dan hari rabu Ust Alvis. Materi hari senin mengkaji Bulughul Maram, hari selasa sirah sahabat, dan hari rabu tafsir Al Qur'an. Hari jum'at ada pelayanan masyarakat antara lain bekam, cek kesehatan dan pagi harinya sekitar jam 6 lebih ada kajian untuk akhwat. Sedangkan kajian akbar belum ada jadwalnya dan bersifat kondisional, dalam satu tahun kurang lebih ada 2 kajian akbar.

Isi materi dari forum kajian rutin lebih menekankan tentang akhlak, ibadah, dan tauhid sedangkan khutbah jum' at materinya dari pembicara, takmir hanya bertugas menyediakan penceramah. Sedangkan materi yang mengangkat isu-isu hangat atau masalah keumatan, biasanya tergantung dari materi dan pembicaranya. Selain masyarakat kampus, masyarakat sekitar kampus atau masjid ada juga yang ikut dalam kajian rutin namun banyaknya dari kampus. Harapan dari takmir, cakupan kajian untuk kedepannya semakin lebih luas tidak hanya warga kampus yang mengikuti kajian. Banyak hal yang telah dilakukan seperti menginfokan agenda tidak hanya disekitar kampus tapi juga ke masjid-masjid sekitar dan terdekat namun yang hadir itu-itu saja, tidak lebih dari 50 orang (putra dan putri). Selain itu, Untuk meningkatkan wawasan keagamaan, masjid kampus Al Mujahidin juga menerbitkan buletin mingguan yaitu, buletin Kalam, terbitnya setiap hari jum'at.

Selain itu untuk mendukung dan memperkuat aktivitas di masjid Al-Mujahidin UNY dibuat beberapa kantor atau lembaga yaitu, LPIM, perpustakaan, unit usaha, dan Ziswaf. LPIM memiliki beberapa program antara lain : 1) Tahsin Al Qur'an, dengan menggunakan metode qiroaty, terdiri dari 9 jilid dengan urutan jilid 1 sampai 6, juz 27, Al Qur'an, ghorib, tajwid dan pra-tashih. 2) Hifdzil Al Qur'an, pilihan program hifdzil yaitu, juz 30, 29, 1 dan program takhassus. 3) Madrasah Thullaaby, pilihan program MT yaitu, MT 1 meliputi aqidah dan Al Qur'an, MT 2 meliputi fiqh sirah dan fiqh dakwah, MT 3 meliputi hadits dan ghazwul fikri. 4) program bahasa arab, pilihan level 1 Durusullughoh jilid 1 dan level 2 Durusullughoh jilid 2.

Selanjutnya perpustakaan masjid Al Mujahidin UNY yang berada di gedung Islamic Education centre (IEC) menyediakan buku-buku agama (Fiqh, hadits 
dll), motivasi, pendidikan, pengetahuan umum, novel dan majalah islami. Buku-buku tersebut dapat dibaca ruang perpustakaan atau bisa juga dipinjam dengan syarat mendaftar terlebih dahulu menjadi anggota perpustakaan. Adapun jadwal buka perpustakaan hari senin sampai jum'at jam 09.00-15.00 wib. Sedangkan lembaga Lazis Mujahidin menerima dan menyalurkan zakat, infak dan shadaqah dan unit usaha Mujahidin merupakan koperasi atau toko yang menyediakan barang atau alat keperluan shalat. Penyelenggara atau pengurus elemen/lembaga masjid adalah takmir. Sebenarnya elemen berdiri sendiri namun ada korelasi dengan takmir.

\section{Peran Masjid Kampus Dalam Penguatan Ideologi Islam Eksklusif}

Masjid kampusmemiliki peranstrategis dalam membangun dan membentuk karakter mahasiswa. Dengan adanya masjid kampus diharapkan mahasiswa diharapkan dapat memanfaatkannya sebagai sarana untuk pengembangan kompetensi diri, memupuk dan memperkuat karakter diri melalui kajiankajian keagamaan Islam, peribadatan maupun sebagai pusat syiar Islam kepada masyarakat luas.

Menurut Mohammad Nuh sedikitnya ada tiga peran penting masjid dalam sebuah perguruan tinggi. pertama, pencipta atmosfir kesejukan. Kalau atmosfir sejuk tanaman akan tumbuh dengan baik. Benih-benih kemuliaan akan tumbuh subur. Kedua, masjid kampus harus ikut terlibat dalam proses menanam dan menyemai benih-benih kemulian. Masjid kampus dapat berperan serta mulai dari hal-hal sederhana seperti bimbingan awal akademik, terlibat dalam hal pendidikan keagamaan dan hal lainnya. ketiga, yang tidak kalah pentingnya adalah ikut mencari benih kebaikan.

Masjid dapat berfungsi ideal jika dikelola secara ideal pula. Dan masjid kampus memiliki peluang yang lebih besar untuk menghimpun para jama'ah yang siap mengelola secara ideal. Mereka pada umumnya memiliki idealisme dan waktu yang relatif bebas. Namun, memang ada kesan eksklusif yang melekat pada sebagian aktivis masjid kampus. Akan tetapi, jika ditelusuri akar pertumbuhannya, eksklusifisme itu sebetulnya menjadi sebuah keniscayaan sebagai implikasi proses sosial yang dilalui. Interaksi di antara para aktivis masjid kampus relatif intensif. Karenaitu, kegiatan apapun yang mereka lakukan hampir selalu berlangsung hingga proses internalisasi. Proses internalisasi 
inilah yang memungkinkan dapat membentuk watak atau kepribadian yang revolusionir sehingga terkesan eksklusif.

Para aktivis masjid kampus umumnya berlatar belakang heterogen. Mereka ada yang memiliki latar pendidikan agama yang kuat, seperti para santri dari pesantren-pesantren atau siswa madrasah. Tetapi ada pula diantaranya yang mungkin baru mengenal Islam ketika mereka mulai berinteraksi di kampus. Sikap keberagaman para aktivis masjid kampus yang bergerak di antara dua corak pemahaman keagamaan ini juga akan membentuk dinamika sosial yang tidak biasa.

Dalam banyak kasus sikap beragama yang eksklusif dapat mendorong tindakan kekerasan, tetapi Islam dengan sigap telah mengantisipasi potensi tersebut agar tidak berkembang secara liar. Hal itu dapat secara nyata dilihat dari berbagai teks Al-Qur'an seperti, surat Al-An'am ayat 108 yang secara tegas melarang umat Islam memaki tuhan-tuhan selain Allah. dalam interaksi sosial seringkali tidak bisa dihindari terjadinya ketegangan dan perdebatan antar umat beragama, namun demikian, Al-Qur'an secara tegas mengharuskan umat Islam untuk melakukan perdebatan tersebut dengan cara yang sebaik-baiknya.

\section{Penutup}

Penelitian ini menemukan bahwa: (1) Masjid kampus memiliki karakteristik masing-masing tergantung takmir dan aktivisnya. Kecenderungan terjadi ekslusivitas bersumber pada siapa takmirnya. Apabila takmirnya mempunyai kecenderungan ekslusif maka keberadaan masjid juga demikian; (2) Bentuk program dan kegiatan sebenarnya masjid kampus memiliki kesamaan tujuan yakni hendak menghadirkan Islam di tengah kampus dan masyarakat yang tengah berubah dalam hal politik, ekonomi, budaya dan sosial; (3) Pengelolaan masjid kampus secara ideal merupakan cikal bakal awal menguatnya gerakan keagamaan. Gerakan keagamaan ini menghadirkan interaksi antar aktivis semakin intensif sehingga melalui proses internalisasi menumbuhkan dan membentuk watak atau kepribadian yang revolusionir. 


\section{DAFTAR PUSTAKA}

Abu Zayd, Nasr Hamid. 1995. al-Tafkir fi Zaman al-Takfir. Kairo: Maktabah Madbuli.

Arikunto, Suharsimi. 1997. Prosedur Penelitian Suatu Pendekatan Praktek Edisi Revisi IV. Jakarta: Rineka Cipta.

Aziz, Abdul. 2006. Varian-Vatrian Fundamentalisme Islam Indonesia. Jakarta: Diva Pustaka.

Azra, Azyumardi. 2002. “Kelompok 'Sempalan' di Kalangan Mahasiswa PTU: Anatomi Sosio-Historis", dalam Fuaduddin \& Cik Hasan Bisri, Editor (2002), Dinamika Pemikiran Islam di Perguruan Tinggi, Ciputat: Logos.

Azra, Azyumardi. 2006. Pergolakan Politik Islam: Dari Fundamentalisme, Modernisme hingga Post-Modernisme. Jakarta: Paramadina.

Azwar, Saifuddin. 2004. Metode Penelitian Cet. 5. Yogyakarta: Pustaka Pelajar.

Budhi Munawar Rachman. 1997. "Beragama di Tengah Agama Orang Lain”, artikel dimuat dalam Majalah IDEA Edisi 09/VI/1997.

Echols, John M. dan Hassan Shadily. 2005. Kamus Inggris Indonesia: An English. - Indonesian Dictionary. Jakarta: PT Gramedia.

Fatimah. 2004. Muslim-cristian relations in the new order indonesia: the Exclusivits and Inclusivits muslim' perspective".

Gulo,W. 2002. Metodologi Penelitian. Jakarta: Grasindo.

Husain A \& Wahab. 2004. Pembinaan Kerukunan Hidup Umat Beragama; Refleksi Cendikiawan Menuju Kesadaran Umat. Yogyakarta: Ar-Rijal.

Martin van Bruinessen. 1992. "Gerakan sempalan di kalangan umat Islam Indonesia: latar belakang sosial-budaya" ("Sectarian movements in Indonesian Islam: Social and cultural background"), Ulumul Qur'an vol. III No. 1, 1992.

Miles, Matthew, B.\& A. Michhael Huberman. 1992. Analisis Data Kkualitatif, Tjetjep Rohendi rohidi (terj). Jakarta: UI Press.

Madjid, Nurcholis. 1998. Dialog Diantara Ahli Kitab: Sebuah Pengantar, kata pengantar untuk George B. Grose and Benjamin J. Hubbard (editor)., Tiga Agama Satu Tuhan: Sebuah Dialog, terj. Santi Inra Anstuti. Bandung: Mizan.

Moelong, Lexy J. 2004. Metodologi Penelitian Kualitatif. Bandung: Remaja Rosdakarya. 
Haedar Nashir. 1997. Agama Dan Krisis Kemanusiaan Modern. Yogyakarta: Pustaka Pelajar.

Sasmono, www,mail-archive.com. Dikutip pada tanggal 21 Mai 2007.

Shihab, Alwi. 2005. Islam Inklusif: Menuju Sikap Terbuka dalam Beragama. Bandung: Mizan.

Syamsuddin, Din. 1999. “Usaha Pencarian konsep Negara dalam sejarah Pemikiran Politik Islam"dalam Abu Zahra (ed.), Politik Demi Tuhan: Nasionalisme Religius di Indonesia. Jakarta: Pustaka Hidayah.

Turmudi, Endang dkk. 2005. Islam dan radikalisme di Indonesia. Jakarta: LIPI Press.

Rijal. 2010. Radikalisme Islam Klasik Dan Kontemporer: Membanding Khawarij Dan

Hizbut Tahrir. Jurnal AL-FIKR Volume14 Nomor 2 Tahun 2010. Fakultas

Dakwah dan Komunikasi IAIN Antasari Banjarmasin

Yunanto, S,. 2003. Gerakan Militan Islam di Indonesia dan Asia Tenggara, Jakarta: Tge Ridep institute.

Wijdan, Aden. 2004. Pemikiran dan Peradaban Islam. Yogyakarta: The Asia Fundation dan PSI UII

http:/ / pendetagki.berteologi.net/index.php?option=com_content\&task=view \&id=53\&Itemid=2. Diakses pada tanggal 1 Januari 2007

http://www.bung-hatta.info/tulisan_86.ubh. Diakses pada tanggal 5 februari 2007 